UDC 338.47:657(410)

DOI https://doi.org/10.26661/hst-2020-7-84-12

\title{
COST ACCOUTING AT TRANSPORT SERVICES ENTERPRISE: THE CASE OF THE UNITED KINGDOM
}

\author{
(C) IVANAUSKIENE, RUTA \\ Marijampole University of Applied Sciences (Marijampole, Lithuania) \\ E-mail: ruta.jaruseviciute@gmail.com \\ ORCID iD: http://orcid.org/0000-0002-6877-6003 \\ Маріямпольський університет прикладних наук, вул. П. Арміно 92, LT-68125, Маряямполь, Литва \\ Marijampole University of Applied Sciences, str. P. Armino 92, LT-68125, Marijampole, Lithuania
}

(C) PETROSIENE, BIRUTE்

Marijampole University of Applied Sciences (Marijampole, Lithuania)

E-mail: bir.petr@mkolegija.lt

ORCID iD: http://orcid.org/0000-0002-5160-8249

Маріямпольський університет прикладних наук вул. П. Арміно 92, LT-68125, Маряямполь, Литва

Marijampole University of Applied Sciences, str. P. Armino 92, LT-68125, Marijampole, Lithuania

\begin{abstract}
Cost accounting has emerged from the history of manufacturing. The European industrial revolution of the 18th and 19th centuries, and the concomitant modernization of industry through its mechanization, have created an increasing need for accurate production costs. There is a need to record the production costs incurred using the double entry principle. Although cost accounting has originated in the manufacturing sector, its modern application areas cover a wide range of economic activities. Today, cost accounting is practiced by various sectors of industry, manufacturing, trade, and services. Public sector organizations, such as governments, various departments, also use cost accounting to determine their effectiveness and anticipate opportunities for improvement. Cost accounting is a system used to determine the costs incurred by a business or other organization [4]. This can be defined as a system used to record cost data and to determine the cost of manufacturing a product or providing a service. Managers use the information gathered during cost accounting to control costs and make the business more profitable. Research problem. Understanding how costs change as performance changes is an important part of planning, control and decision-making [10]. There are a number of ways to perform cost estimation and analysis, but according to Sharman [23], many companies are reluctant to change their old costing methods and systems. The owners of these companies are reluctant to accept changes in the company, relying on the high costs of replacing the old system, which may occur due to the introduction of the anew system, as well as the reluctance of accounting staff to learn new methods and accept innovations. Okunbor [20], meanwhile, argues that costs should be used to make a profit, so then the question arises: can cost accounting, and the results it provides, really help not only to achieve more efficient performance results, but also to generate additional profits? Research aim - perform a comparative analysis of the cost accounting of the United Kingdom and Lithuania based on the example of the accounting of the transport company in the United Kingdom. Research objectives: To reveal the discourse of costs and their accounting in the context of the United Kingdom and Lithuania, highlighting the general similarities and differences of the concepts used in relation to both countries. 2. To define the composition of costs in accounting in the United Kingdom, distinguishing the basic principles. 3. To examine the peculiarities of cost documentation, recording and presentation in financial statements of the United Kingdom accounting, defining the cost accounting process. Research object - cost accounting management in the United Kingdom. Research methods: Analysis of scientific literature and legal acts, statistical data analysis, graphic representation and interpretation.
\end{abstract}

Key words: direct costs, overheads, cost documentation, financial statements.

Concepts of costs and theoretical aspects of accountingin the company in the united kingdom and Lithuania

Finance and accounting have gained great importance in today's competitive business world, where companies, organizations and other business entities need to present a true and positive picture of their financial condition. Thus, the application of accounting in the business sector has become an indispensable factor.

According to Mutya [18], cost management is one of the disciplines of business management, as the information collected and provided to management based on cost and management accounting methods not only helps to solve specific problems, but also provides guidelines for making business-friendly decisions.

(C) Ivanauskiene, Ruta, Petrosiene, Birutè, 2021 
In order to properly understand the significance of costs to the company, their distribution and possible accounting methods, it is important to theoretically examine the concept of costs, their distribution, documentation, etc. peculiarities.

In many cases, the terms cost, expediture and expense are used interchangeably, as they tend to overlap, which is especially reflected in the international context. In the European Union, whose official language is English, the definition of costs is identical to such words used in English as cost, expense, expediture, which in Lithuanian means sąnaudas, išlaidas, kaštus. It is noted that at the academic level, according to researchers from both the UK and other countries, a number of cost definitions can be distinguished.

The United Kingdom. Cost is the value of money that an organization spends producing products or providing services. According to Thothadri et al. [27] costs are defined as the sum of the expenses incurred for or attributable to a particular item, or the determination of the cost of a particular item. It is a differentiated amount of cash or cash equivalent paid for a service or good provided that will be reflected in the financial statements as current or noncurrent assets.

According to Tascher and Charifzadeh [25], costs are best described as the loss incurred in order to obtain something from it. In business, costs are usually a monetary expression of all the effort, materials, resources, time, utilities, risks incurred and opportunities missed in evaluating, producing and delivering goods and services [19]. Of course, here the costs are related to the resources used by the company to produce its product, which are allocated according to the system applied by the company to the production of the service or product.

According to Gowthorpe [9], cost accounting can be defined as the process of determining and accumulating the cost price of a product or activity. In this case, it can be defined as an incurrence of expense and control accounting process. According to Maheshwari et al. [15] the concept of costs is linked to their accounting on the basis of quantitative methods, collecting them, classifying, summarizing and interpreting information for three main purposes in relation to the enterprise:

1. operational planning and control;

2. making special decisions related to the company's activities;

3. decisions related to a product or service.
The Chartered Institute of Management Accountants (London) defines cost accounting as a process from the time an expense is incurred and the final liability is determined defining the relationship to the cost units. In a broad sense, this includes the preparation of statistical data, the application of cost control methods and the definition of the profitability of ongoing or planned activities. It includes accounting and cost principles, methods and their application in determining cost and analysis of savings and/or surpluses compared to past experience or standards. According to Mehta [16], costs and their accounting are defined as the application of costing and accounting principles, methods and techniques to the science, art and practice of cost control and the determination of profitability.

At the political level, in the United Kingdom, costs of a company are defined as all expenses incurred in running and managing a business [5]. This definition of costs is treated equally in all UK countries: England, Wales, Scotland and Northern Ireland. At the country level, costs are also divided into two levels, the first [5]:

1. Capital costs are higher costs of acquiring assets that are expected to be used in the business over a reasonable period of time and from which it is expected to have a lasting effect on the enterprise. The law does not set a fixed time, but it can be expected that the property will last for more than a year, such as a computer or office shelves.

2. Revenue costs are expenditures that are shorter in duration and frequently used by a company, e.g. printer ink cartridges or stocks sold that are used for less than a year.

Lithuania. Lithuanian authors also link costs to such definitions as expenses, expenditure, etc. According to Meškeliene [17], who paid a lot of attention to management accounting, costs can be defined as expenses for the production of products from which profits can be made later. Meanwhile, Bendikienè [3] also attributes costs to expenses incurred in connection with the acquisition of fixed assets, inventories, services purchased, advance payments paid to suppliers for goods or services, etc. Žižytė and Tamulevičienė [28], when analyzing the cost price calculation methods according to different areas of activity, express the costs through the expenses incurred in the production of a product or the provision of a service.

Authors of the earlier period like Ivanauskiene [13] emphasize in the context of costs that it is 
expedient to allocate costs according to the company's activities, defining them in the company's accounting policy. The accurate cost accountant, in deciding when to record costs, needs to know what reporting period the asset is used to earn revenue, regardless of when the expense was incurred. This implements one of the general accounting principles, the principle of comparability [14]. According to Andriušaitiene et al. [2] the cost of producing any product includes not only the costs to the company, but also those negative externalities that are borne by the society and are referred to as societal costs. Česnauskè [6] names the costs as a decrease in economic benefits and links them with the legal acts in force in Lithuania, i.e. Business Accounting Standards (hereinafter BAS).

Thus, at the national level, costs are defined as "reductions in the economic benefits arising from the consumption, sale, disposal, impairment and liabilities of an asset during the reporting period that result in a reduction in equity other than a direct reduction" [7]. According to Business Accounting Standard No 11, costs in the country can be divided into sale, general and administrative, other activities, financial and investment activities and income tax expenses.

Thus, theinterpretation of costsand theiraccounting revealed the general similarities and differences between the United Kingdom and Lithuania (see Table 1). At the academic level, the link between costs and definitions such as resources and expenditure becomes apparent. Costs in both countries are inseparable from the expenses incurred. Meanwhile, in the national context, slight differences emerge in the cost distribution and their definition.

The review of costs and their accounting concept interpretation highlighted the principles of accounting simplicity prevailing in the United Kingdom in terms of business, while in Lithuania the situation is more complicated, especially it came to light in terms of legal acts regulating costs accounting.

Analysis of the composition of costs in accounting in the context of the United Kingdom

According to Horngren et al. [12] based on cost accounting, financial and non-financial information related to the acquisition or consumption of resources is estimated and presented. It occupies a particularly important place in the company's entire accounting information system, as it provides information to both management accounting and financial accounting as a subsystem of the accounting information system [24].

Thus, according to Horgren et al. [16] and Stefanović [24], in this case, the costs can be divided into those for obtaining information for financial accounting and for obtaining additional information within the company (see Figure 1).

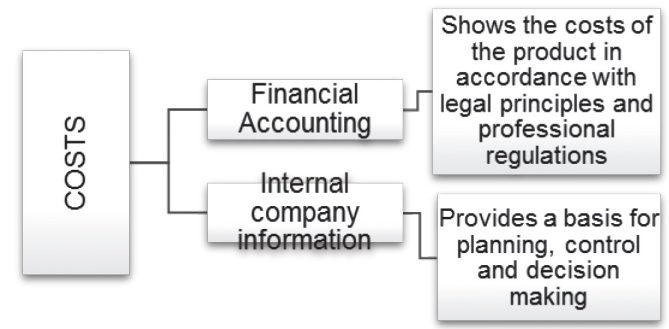

Fig. 1 Distribution of costs in the company according to the use of information

It is noted that financial and cost accounting are based on the same basic principles and use the same records, but each deals with issues specific to itself. Financial accounting shows the profit/loss of the whole business for a certain period of time,

Table 1

Interpretation of costs and their accounting in the context of the United Kingdom and Lithuania

\begin{tabular}{|c|c|c|}
\hline \multirow{2}{*}{ Countries } & \multicolumn{2}{|c|}{ Interpretation of costs and their accounting } \\
\hline & Similarities & Differences \\
\hline $\begin{array}{l}\text { The United Kingdom } \\
\text { (international level) }\end{array}$ & \multirow{2}{*}{$\begin{array}{l}\text { At the academic level, the concept of } \\
\text { costs is related to the expenses incurred } \\
\text { due to the company's activities in } \\
\text { providing a service or producing a } \\
\text { product. They are also associated with } \\
\text { a decrease in non-current or current } \\
\text { assets. } \\
\text { At the national/political level, costs are } \\
\text { usually recorded as they are incurred } \\
\text { and the final commitment is defined as } \\
\text { the relationship to the cost units. }\end{array}$} & $\begin{array}{l}\text { At the national/political level, costs are defined as } \\
\text { expenses incurred to run or manage a business. } \\
\text { Costs are divided into capital and income expenses. } \\
\text { Costs are related to loss, monetary expression of } \\
\text { total expenses, and so on. }\end{array}$ \\
\hline $\begin{array}{c}\text { Lithuania } \\
\text { (national level) }\end{array}$ & & $\begin{array}{l}\text { At the national/political level, costs are related } \\
\text { to the decrease in economic benefits due to the } \\
\text { consumption, sale, impairment of assets during the } \\
\text { reporting period, when this results in a decrease in } \\
\text { equity. } \\
\text { Expenses are divided into sale, general and } \\
\text { administrative expenses, other activities, financial } \\
\text { and investment activities and income tax expenses. }\end{array}$ \\
\hline
\end{tabular}

(C) Ivanauskiene, Ruta, Petrosiene, Birutè, 2021 
and cost accounting allows to obtain unit costs and profit and/or loss for different product lines/ services.

According to Pope, the importance of both cost accounting and financial accounting cannot be underestimated [21]. They both differ in terms of meaning, purpose, presentation method, recording, profit analysis, reporting frequency, degree of accuracy, and method of estimating inventories.

According to the UK government it is recommended to apply the structure of the chart of accounts in the company accounting, the costs are assigned to class 7-9 accounts. Costs can be defined as the company's total expenses that have to be paid when producing or providing services. According to Drury [8], expenses can be distinguished into direct and indirect expenses. Direct costs consist primarily of direct materials and labour that are easily and accurately identifiable with a particular cost item. Therefore, indirect expenses cannot be determined specifically and exclusively on the basis of the stated expense object [8], Hansen, Mowen [11]

Costs in the UK can be distinguished in a variety of ways, depending on both the type of business

Table 2

Comparison of cost accounting and financial accounting

\begin{tabular}{|c|c|c|c|}
\hline No. & $\begin{array}{c}\text { Basis of } \\
\text { comparison }\end{array}$ & Cost accounting & Financial Accounting \\
\hline 1. & $\begin{array}{l}\text { Reikšmè } \\
\text { Importance }\end{array}$ & $\begin{array}{l}\text { Cost accounting makes it easy to } \\
\text { identify, monitor and control the } \\
\text { various costs incurred in a business }\end{array}$ & $\begin{array}{l}\text { Financial accounting records business } \\
\text { financial information to reflect the } \\
\text { company's profitability and fair financial } \\
\text { condition on a particular day }\end{array}$ \\
\hline 2. & Purpose & Cost reduction and control. & $\begin{array}{l}\text { Manages all accounting of financial } \\
\text { transactions, assesses profit and financial } \\
\text { condition. }\end{array}$ \\
\hline 3. & $\begin{array}{l}\text { Information } \\
\text { fixed }\end{array}$ & $\begin{array}{c}\text { All information related to materials, } \\
\text { labour and overhead is used in the } \\
\text { production process }\end{array}$ & $\begin{array}{l}\text { All transactions that can be measured in } \\
\text { monetary terms }\end{array}$ \\
\hline 4. & $\begin{array}{c}\text { Type of } \\
\text { expenses }\end{array}$ & Both past and estimated expenses & Past expenses only. \\
\hline 5. & $\begin{array}{l}\text { Method of } \\
\text { submission }\end{array}$ & $\begin{array}{l}\text { No legal forms and optional } \\
\text { submission }\end{array}$ & $\begin{array}{c}\text { Prepared in accordance with accounting } \\
\text { concepts and conventions, standards and } \\
\text { in compliance with various laws and } \\
\text { regulations }\end{array}$ \\
\hline 6. & $\begin{array}{l}\text { Reporting } \\
\text { period }\end{array}$ & $\begin{array}{l}\text { There is no set time period. Reports } \\
\text { have been prepared as necessary. }\end{array}$ & $\begin{array}{c}\text { Financial statements are prepared at the end } \\
\text { of the reporting period, which is usually } 1 \\
\text { year }\end{array}$ \\
\hline 7. & Users & $\begin{array}{l}\text { Internal stakeholders like the } \\
\text { management of the organization. }\end{array}$ & $\begin{array}{l}\text { All stakeholders, including internal } \\
\text { and external parties such as customers, } \\
\text { creditors, government, shareholders, etc. }\end{array}$ \\
\hline 8. & $\begin{array}{l}\text { Inventory } \\
\text { valuation }\end{array}$ & Price incurred & $\begin{array}{l}\text { Costs or net realizable value, taking into } \\
\text { consideration the one which is lower }\end{array}$ \\
\hline 9. & $\begin{array}{l}\text { Mandatory } \\
\text { nature }\end{array}$ & $\begin{array}{l}\text { No, except for manufacturing } \\
\text { plants, this is mandatory. }\end{array}$ & Yes, for all companies. \\
\hline 10. & Profit analysis & $\begin{array}{l}\text { Typically, profit is analyzed for a } \\
\text { particular product, job, batch, or } \\
\text { process, thus enabling management } \\
\text { to eliminate less profitable product } \\
\text { lines and increase profits by } \\
\text { focusing on more profitable ones. }\end{array}$ & $\begin{array}{l}\text { Revenue, expenses and profits are analyzed } \\
\text { along with the entire business. }\end{array}$ \\
\hline 11. & Forecasting & $\begin{array}{l}\text { Forecasting can be done using } \\
\text { budgeting methods. }\end{array}$ & It is not possible to predict at all. \\
\hline
\end{tabular}


and turnover, area of activity, etc., but are most commonly referred to as: direct, overhead and general.

1. Direct Expenses. These expenses are defined as the cost of materials and labour involved in the production of a particular product or service provision [22].

2. Overheads. These are all expenses related to the production activity of the service/product, but which cannot actually be taxed directly on a particular product/service. Typically, the classification of accounts in accounting is based on key functions, elements, or behaviours [1].

3. General expenses - expenses incurred in carrying out its day-to-day operations by a business, separately from selling and administrative expenses, general and administrative expenses [21]. Selling, General, and Administrative (SG\&A) expenses comprise the total operating costs of the company.

Thus, the composition of costs, in the British context, can be identified in terms of their allocation. In the company, costs are allocated according to the reason for their incurrence. In accounting, costs, depending on their qualification, are classified in these classes 5, 6 and 7-9.

Cost accounting research in a transport service company

An individual logistics company providing transport services to retailers, food manufacturers, growers and importers in the United Kingdom. One of the main goals of the company is to ensure that the cargo will be delivered to its place with high quality and in the shortest possible time. Modern facilities and a modern fleet park allow us to fulfill the commitment to provide economical and highly efficient services that meet the individual needs of the customer. Under the UK legal framework and taking into consideration the company's turnover [5], it can be classified as a very small individual company. Under the legal system in the United Kingdom, the company regulates its activities:

- UK GAAP (Generally Accepted Accounting Practice) [26].
- Companies Act [26];

- The Limited Liability Partnerships (Accounts and Audit) [5];

- The Small Companies (Micro-Entities Accounts) Regulations [22]).

In accordance with the basic laws, the company's regulations have been formed to ensure the directionality and consistency of the activities carried out. In accordance with the main documents regulating the company's activities, the company also organizes accounting.

Taking into consideration that preference is given for electronic documents in the UK, all company accounting is computerized. The company currently uses two computer programs, one for accounting operations and the other for calculating employee gross wages:

- Sage 50 - a program that performs and records all accounting operations.

- Payroll - a program designed for gross wages transactions only.

Subsequently, the data of the general summary according to the fact sheets

(weekly, monthly) are registered in the Sage 50 program.

An individual company is required by the UK law to submit the following reports:

- a balance sheet in one of the specified formats specified in the relevant regulations (mandatory);

- Directors' report (mandatory);

- income (loss) statement in accordance with the relevant legislation (mandatory);

- auditors' report (optional);

- any explanations of accounts [5].

In the United Kingdom, the accounts required for the statement of balance sheet: the statement of assets, liabilities and equity of the owner (shareholders) and profit (loss), various types of income and expenditure (see Table 3).

When considering cost accounting in a company, it is important to clearly define the direction of the research by including all the elements relevant

Table 3

Structure of the chart of accounts in the United Kingdom

\begin{tabular}{|c|c|c|c|}
\hline Types of accounts & Accounts No. & D & C \\
\hline Sales & $(4000-4905)$ & & + \\
\hline Purchases & $(5000-5201)$ & + & \\
\hline Direct Expenses \& Overheads & $(6000-9999)$ & + & \\
\hline Assets & $(0010-1250)$ & + & + \\
\hline Liabilities & $(2100-2330$ & & + \\
\hline Capital \&Reserves & $(3000-3200)$ & & \\
\hline
\end{tabular}

(C) Ivanauskiene, Ruta, Petrosiene, Birutè, 2021 
to cost accounting. As can be seen, the course of the research was performed in stages: analysis of scientific literature and documents and analysis of cost accounting in the company.

Company costs include classes 5 to 9 of the chart of accounts. As shown in Figure 2, costs are divided into direct, general, and overheads (see Figure 2).

In this case, the largest package of expenses incurred by the company is overheads, which could otherwise be related to sales and the overall activities of the company.

These expenses include wages and salaries and all related costs, insurance costs, rental of premises and costs necessary for their maintenance and operation, maintenance of vehicles, etc. As can be seen from the breakdown of costs, although the accounting is strictly regulated, it is quite simple, emphasizing the principle of solidarity and trust in companies.

General costs include depreciation, insurance and clothing (having in mind in this case driver clothing for the company 's activities, which can be purchased both by the company and by the employees themselves.

Thus, Figure 2 shows that the cost allocation for the company remains clearly structured and simplified. The company can also distribute assets in this way, taking into account the Government's simplified requirements for companies [5].
The cost accounting process in a company usually takes place in two ways, which are based on the input of initial documents into the company's accounting process (see Figure 3).

Thus, as shown in Figure 3, the company's cost accounting begins with the receipt of the initial document from the outside, which continues as follows:

The first case, as initial documents on the costs incurred, various invoices, and other supporting documents for the costs, first reaches the head or managers of the company (if the expenses are related to the direct activities of the company - transport services). This document is then passed on to the company's accountant, who records everything in a computer program, usually on the same day or in the near future. This document is then archived and stored for 6 years.

The second case, as an initial document is formed within the company, a perfect example is Gross Wages register prepared and compiled by an accountant, later sent to the director for a visa and then the data are validated in the program.

Next, the costs recorded in the computer program are transferred to the Trial Balance Sheet, and the financial statements are formed after its approval. In this way, costs are recorded in the accounts.

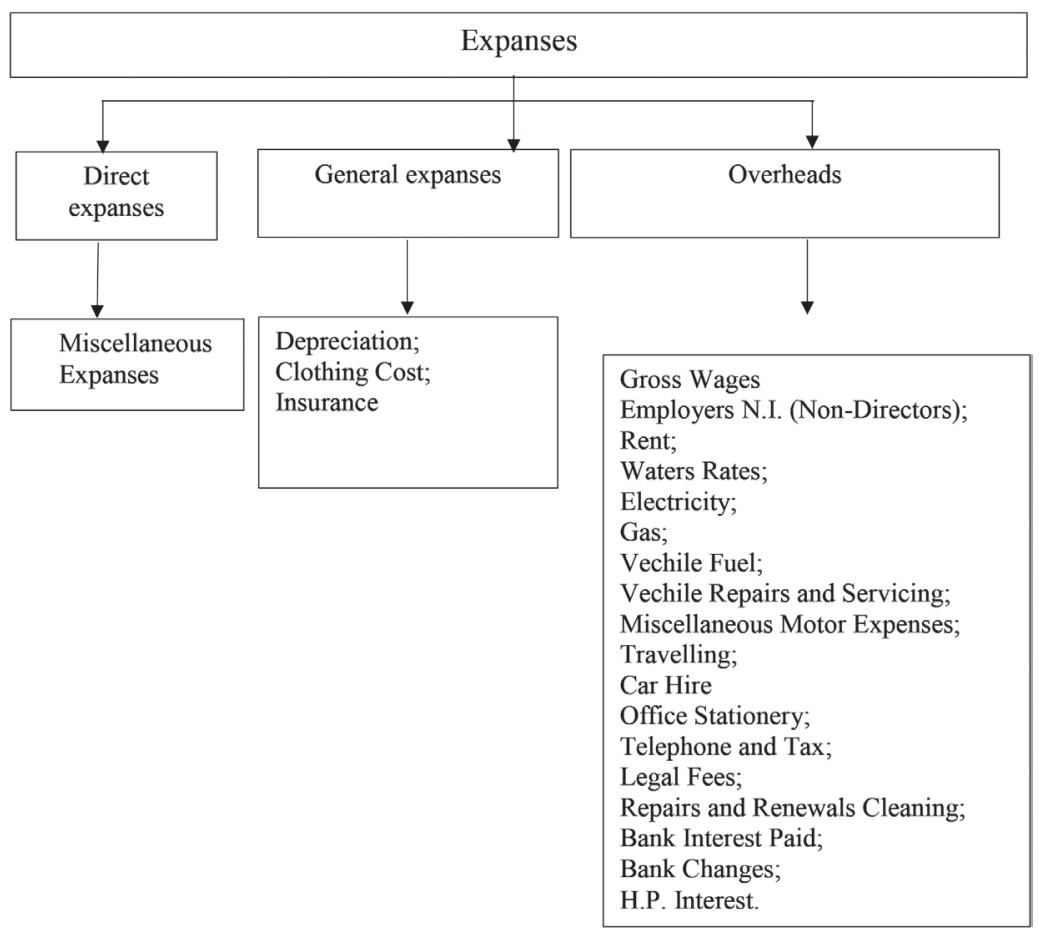

Fig. 2. Allocation of costs in the company 


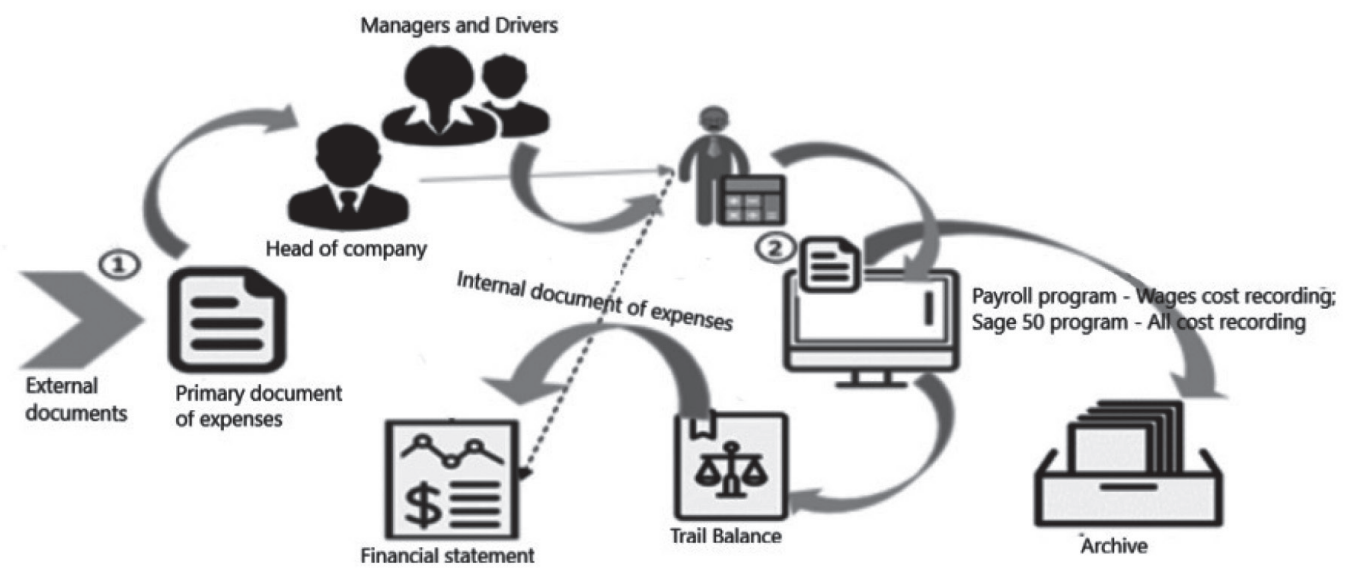

Fig. 3 Recording scheme of the company's cost accounting

General and administrative expenses, account numbers

\begin{tabular}{|c|c|}
\hline $\mathbf{7 0 0 0 - 9 9 9 9}$ & Overheads \\
\hline $7000-7012$ & Gross Wages \\
\hline $7200-7203$ & Heat, Ligt and Power \\
\hline $7300-7350$ & Motor Expenses \\
\hline $7550-7553$ & Telephone and Computer charges \\
\hline $7600-7606$ & Professional Fees \\
\hline $7800-7803$ & Maintenance \\
\hline $7900-7908$ & Bank Charges and Interest \\
\hline
\end{tabular}

General and administrative expenses of the company include expenses in class 7 (see Table 4):

These expenses include the following: computer equipment costs, furnishing of rented premises, lowvalue purchases, telephone services, utilities, Internet services, various bank charges, etc.

All expenses are paid according to the received invoices and recorded in the accounting program Sage 50. Upon receipt of the invoices, the following invoice correspondence are registered:

\begin{tabular}{|c|c|c|}
\hline Account & Debit & Credit \\
\hline Overheads & + & \\
\hline Sundry Creditors & & + \\
\hline
\end{tabular}

General and administrative expenses are recorded in the accounts and shown in the financial statements in the reporting period in which they are incurred.

In payroll accounting, it is important to distinguish between employee taxes, which are deducted from employees' gross pay and paid by the employee, and employer's taxes, which are in addition to net pay and paid by the employer. Taking this into consideration, gross pay can be attributed to the costs incurred.

In order to properly understand the costs related to gross pay and their recording in the accounting, it is important to properly understand their calculation methodology. Both pay taxes are usually calculated by the employer and paid to the relevant tax office (see Figure 4).

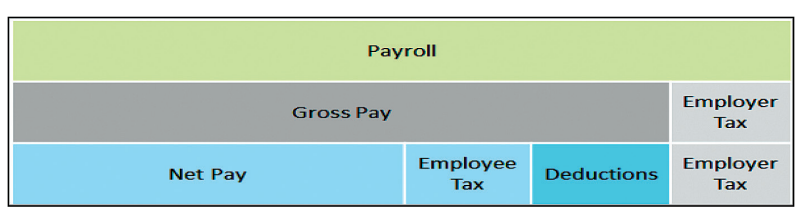

Fig. 4 Payroll detail

Next, in order to continue to register and properly record the costs incurred with gross pay, first of all the following entries are recorded in the Payroll accounting program:

1) Gross pay:

\begin{tabular}{|c|c|c|}
\hline Account & Debit & Credit \\
\hline Gross Wages & + & + \\
\hline $\begin{array}{c}\text { Employee tax } \\
\text { control) }\end{array}$ & & + \\
\hline $\begin{array}{c}\text { Other deductions } \\
\text { control }\end{array}$ & & + \\
\hline Net pay control & & + \\
\hline
\end{tabular}

Gross pay is expenses included in the income statement.

2) Employee tax liabilities (employer tax):

\begin{tabular}{|c|c|c|}
\hline Account & Debit & Credit \\
\hline Employer tax & + & \\
\hline Employer tax control & & + \\
\hline
\end{tabular}


The first entry is the expense included in the income statement, and the second entry is a liability to the tax administrator recorded in the balance sheet control account.

3) Net pay is gross pay that a person earns after deducting taxes and other settlements, such as pension contributions. This is the amount of pay a person has to maintain. The net pay formula is defined in Figure 5.

Net pay $=$ Gross pay - Taxes - Deductions

Fig. 5 Payroll detail, net pay

Operations registered in Payroll program:

\begin{tabular}{|c|c|c|}
\hline Account & Debit & Credit \\
\hline Net pay control & + & \\
\hline Bank Account & & + \\
\hline
\end{tabular}

4) Payment to the Tax inspection (HMRC):

\begin{tabular}{|c|c|c|}
\hline Account & Debit & Credit \\
\hline Employee tax control & + & \\
\hline Bank Account & & + \\
\hline
\end{tabular}

5) Registration of other deductions:

Other deductions are paid to the relevant institution, such as a pension scheme, health care system or union, and control accounts are cleared using the following payroll deduction accounting journal:

\begin{tabular}{|c|c|c|c|}
\hline \multicolumn{2}{|c|}{ Account } & Debit & Credit \\
\hline Other deductions control & + & \\
\hline Bank Account & & \multicolumn{2}{|c|}{+} \\
\hline
\end{tabular}

Employee pay arranged in the Payroll program is transferred to the Sage50 program, which is included in the preparation of financial statements.

Cost recording related to inventory. When the acquisition of inventory is recorded both in the accounting and in the preparation of the financial statements, it is recognized at acquisition cost. In accounting, the company registers inventory in the current assets account 1001 - Inventory.

When inventory is consumed, its carrying amount is recognized as an expense in the period in which they are incurred. Consumption of inventory is recorded in the accounting on a regular basis, recording the earned income for the provided services and writing off the used stock to expenses. In the consumed inventory account 7304 - Miscellaneous Motor Expenses are recorded.

Accounting for costs related to long - term tangible asset operation. The company classifies the operating costs of long - term tangible asset as overheads and includes: vehicle fuel used, vehicle maintenance taxes, vehicle insurance costs, etc.:

\begin{tabular}{|c|c|}
\hline $\mathbf{7 0 0 0}-$ & Overheads \\
\hline $\mathbf{9 9 9 9}$ & Motor Expenses \\
\hline 7300 & Vehicle Fuel \\
\hline 7301 & Vehicle Repairs and Servicing \\
\hline 7302 & Vehicle Licences \\
\hline 7303 & Vehicle Insurance \\
\hline 7304 & Miscellaneous Motor Expenses \\
\hline 7305 & Congestion Charges \\
\hline 7306 & Mileage Claims \\
\hline 7350 & Scale Charges \\
\hline
\end{tabular}

Costs related to the asset depreciation. Depreciation is the gradual transfer of the initial expenses of a fixed asset from the balance sheet to the profit and loss account. The transfer is usually done in Sage50. It could be said that depreciation is the "release" of fixed assets, i.e. the percentage of the price of fixed assets becomes an expense and the carrying amount of fixed assets is lower.

All tangible assets in the company are accounted using the Straight Line Depreciation method. In this case, the same depreciation is applied every year during the period of the asset operation.

In England, another method known as the Reducing Balance Depreciation method can be used to calculate the depreciation of asset. This method may be appropriate when non-current assets gradually lose its value, but its useful life cannot be estimated accurately.

Depreciation is calculated at the end of the reporting period and is recorded in Sage50:

\begin{tabular}{|c|c|c|}
\hline Account & Debit & Credit \\
\hline Depreciation expense & + & \\
\hline $\begin{array}{c}\text { Accumulated } \\
\text { depreciation }\end{array}$ & & + \\
\hline
\end{tabular}

Here, depreciation costs are calculated $=(\operatorname{cost}$ price of assets - value of fixed assets) / useful life.

The research has revealed both the specifics of cost accounting in the UK and areas for improvement seeking to improve operational efficiency for the company. As can be seen, the largest part of the company's costs is covered by overheads, which has confirmed the feature of the UK cost accounting already highlighted in the theoretical part. Costs in the company are recorded in a double entry in the period they are incurred. Depending on the company's activities, the recording of costs in accounting can be divided into costs related to pay, 
services, inventories, depreciation and operation of tangible assets.

The research has revealed that in the case of a company, the largest part of the costs incurred is related to pay and other expenses related to the main activities of the company, i.e.vehicle fuel, vehicle maintenance, etc.

\section{CONCLUSIONS}

1. According to both the British and Lithuanian authors, who have examined the cost accounting, the costs are related to the expenses incurred to run the company. On the other hand, at the national/political level of countries, the interpretation of these concepts has not only similarities but also differences. The similarity is related to the recording of costs, which are recorded in the accounts when they are incurred and the final liabilities that define the relationship with the cost units are identified. Meanwhile, the differences between the interpretation and application of costs in accounting in the United Kingdom and Lithuania have become apparent in terms of legislation and the definition of accounting, an excellent example of which is the regulation of cost allocation.

2. An examination of the composition of costs in accounting in the United Kingdom reveals the principle of apportionment of expenses, dividing them into general, direct and overheads. Costs are recorded in the accounts using double entry when they are incurred. The costs are reflected and broken down in detail in the Trial Balance Sheet, which not only allows for a detailed analysis of the cost allocation, but also allows the accountant to verify the correct recording of costs in the accounts by comparing the debit with the credit side.

3. Cost accounting in the UK is based on a process that can be defined as a cycle. The recording of costs in the accounts is based on initial documents, which are archived and kept for six years. These documents are later recorded in the Sage50 or Payroll accounting program and transferred to the Trial Balance Sheet, on the basis of which analyses are made of both the costs and the overall financial condition of the company.

\section{References}

1. Ambarasu, J. Overhead, [žiūrèta 2020-04-12]. Prieiga per internetą: file:///C:/Users/testas5/Downloads/OverheadJoseph-Anbarasu\%20(2).pdf

2. Andriušaitienè, D ir kt. (2016). Ekonomikos teorija. Vilnius: Vilniaus Gedimino technikos universitetas, 2016. ISBN 9786094578915.

3. Bendikienè, D. (2019). Finansinè apskaita. Metodinė priemonè. Šiauliai: Šiaulių universitetas, 2019. ISBN 978-609-8179-21-7

4. Boersma, R. ( 2013). IR KT. Principles of cost accounting. Southern Amfrica: Oxford university press, 2013. ISBN 9780199045488

5. Companies House. Companies House, Gov UK, [žiūrèta 2020-05-02]. Prieiga per internetą: https://www.gov.uk/government/organisations/companies-house.

6. Česnauskè, J. (2018). Apskaitos pagrindai: teorija ir praktika. Mokomoji knyga. Kaunas: Kauno kolegija, 2018. ISBN 978-9955-27-531-2.

7. Dèl 11-ojo verslo apskaitos standarto „, sq̨audos “ tvirtinimas: Audito ir apskaitos tarnybos direktoriaus $2015 \mathrm{~m}$. birželio 16 d. įsakymas Nr. VAS-38, TAR, 2015-06-16, Nr. 9640.

8. Drury, C. (2012). Management and Cost Accounting, Eighth Edition. Thomson Learning, 2012.

9. Gowthorpe, C. (2018). Business Accounting \& Finance: Fourth edition. China: RR Donnelley, 2018. 9.

10. Hansen, Don R., Mowen, M. M. (2015). Cornerstones of Cost Management, 3th ed. Mason, OH: Cengage Learnin.

11. Hansen, Don R., Mowen, M. M., Guan, L. (2009). Cost management: accounting \& control, 6th ed. Mason: South-Western.

12. Horngren, C.T. ir kt. (2005). Management and Cost Accounting, Third Edition. FT Prentice Hall, Pearson Education Ltd.

13. Ivanauskiene, A. (2016). Buhalterinès apskaitos pagrindai. Vilnius.

14. Kanapickienė, R., Rudžionienė, K., Jefimovas, B. (2008). Finansine apskaita. Vilnius: Vilniaus universiteto leidykla. ISBN 978-9955-33-286-2

15. Maheshwari, S. N., Maheshwari, S. K., Maheshwari S. K. (2012). A Textbook of Accounting Management: Third edition. India: Vikas publishing house Pvt Ltd..

16. Mehta, B., K. (2006). Cost and Management Accounting-Latest Edition. Agra: SBPD Publications, 2016. UK Public General Acts. Company Act 2006 November 8, c 46..

17. Meškelienè, A. (2011). Valdymo apskaita. Mokomoji medžiaga su praktinèmis užduotimis. Klaipėda: Socialinių mokslų kolegija.

18. Mutya, T. (2018). Cost Control: A Fundamental Tool towards Organisation Performance. Iš: Journal of Accounting \& Marketing, 2018 m. Nr. 7 (3), p. 1-11. ISSN: 2168-9601. 
19. Nwokoye, E.S., Ilechukwu, N. (2018). Principles of Economics. Department of Economics, Nnamdi Azikiwe University Awka Nigeria..

20. Okunbor, J. A. (2013). The application of cost behaviour and estimation in organisational decision making process. Journal of Research in National Development, Nr. 11(1), p. 217-227..

21. Pope, S. (2019). General Ledger Account: Accounting Record Keeping Books , Simple Income Expense Book, Record Expenses \& Income 8.5" x 11". USA.

22. Regulatory Policy Commitee. Evaluating costs and benefits for regulatory purposes: direct and indirect impacts of regulation on business. [žiūreta: 2020-04-23]. Prieiga per internetą:

https://assets.publishing.service.gov.uk/government/uploads/system/uploads/attachment_data/file/790107/ Evaluating_Costs_and_Benefits_for_Regulatory_Purposes_-_Direct_and_Indirect_Impacts_of_Regulation_on Business_April_2015.pdf

23. Sharman, P. A. (2003). The case for management accounting. Strategic Finance, Nr. 85(4), p. 42-47.

24. Stefanović, R. J. (2011). Cost accounting and company management in a world without walls. International Conference $\gg$ A World Without Walls 2010: An International Conference on Peacebuilding, Reconciliation and Globalization in an Interdependent World«, Institute for Cultural Diplomacy (ICD), Participant Papers, Conference Book-88, Berlin, Germany.

25. Taschner, A., Charifzadeh, M. (2016). Management and Cost Accounting. Tools and concept in a Central European Context. Germany: Wiley Verlag \& Co. KgaA.

26. The Companies, Partnerships and Groups (Accounts and Reports) Regulations,2015. [interaktyvus]. [Žiūrèta: 2019-12-13]. Prieiga per internetą: https://www.legislation.gov.uk/ukdsi/2015/9780111127896

27. Thothadri, S., Nafeesa, S. Syed ahammed jalalutheen, R. B. (2019). Cost Accounting. India: McGraw Hill Education (India) Private Limited.

28. Werner, R. (2014). How do banks create money, and why can other firms not do the same? An explanation for the coexistence of lending and deposit taking. International Review of Financial Analysis, Nr. 36, 71 - 77.

29. Žižytė, V., Tamulevičenè, D. (2018). Veiklos sritimis grịsto savikainos skaičiavimo metodo taikymas: buhalterines ir audito paslaugas teikiančios įmonès atvejis. Buhalterinès apskaitos Teorija ir Praktika tomai 17-18.

IВАНАУСКЕНЕ, РУТА - бакалавр Маріямпольського університету прикладних наук (Маряямполь, Литва) E-mail: ruta.jaruseviciute@gmail.com

ORCID iD: http://orcid.org/0000-0002-6877-6003

ПЯТРОШЕНЕ, БІРУТЕ - лектор Маріямпольського університету прикладних наук (Маряямполь, Литва) E-mail: bir.petr@mkolegija.lt

ORCID iD: http://orcid.org/0000-0002-5160-8249

\title{
ОБЛІК ВИТРАТ НА ПІДРИЕМСТВІ ТРАНСПОРТНИХ ПОСЛУГ: ПРИКЛАД ВЕЛИКОБРИТАНІЇ
}

\begin{abstract}
Анотація
Облік витрат виник з історії виробництва. Свропейська промислова революція 18-19 століть і супутня модернізація промисловості за рахунок ії механізації викликали зростаючу потребу в точних виробничих витратах. Необхідно було реєструвати виробничі витрати за принципом подвійного запису. Хоча облік витрат зародився у виробничому секторі, його сучасні сфери застосування охоплюють широкий спектр економічної діяльності. Сьогодні госпрозрахунок практикується у різних секторах промисловості, виробництва, торгівлі та послуг. Організації державного сектора, а саме уряду, різних відомств, також використовують облік витрат для визначення своєї ефективності і прогнозування можливостей для підвищення ефективності. Облік витрат - це система, яка використовується для визначення витрат, понесених бізнесом або іншою організацією. Ї̈̈ можна визначити як систему, яка використовується для запису даних про витрати і визначення вартості виробництва продукту або надання послуги. Керівники використовують інформацію, зібрану під час обліку витрат, для контролю витрат і підвищення прибутковості бізнесу. Проблема дослідження. Розуміння того, як змінюються витрати при зміні продуктивності, є важливою частиною планування, контролю та прийняття рішень. Існує кілька способів оцінки та аналізу витрат, згідно Шармана, тому багато компаній не хочуть міняти свої старі методи і системи розрахунку витрат. Власники компаній неохоче приймають зміни у компанії, покладаючись на високі витрати на заміну старої системи, які можуть виникнути через впровадження нової системи, а також на небажання бухгалтерського персоналу вивчати нові методи і приймати нововведення. Тим часом Окунбор стверджує, що витрати слід використовувати для отримання прибутку, тому виникає питання: чи може облік витрат і результати, які він дає, дійсно допомогти не тільки у досягненні більш ефективних результатів продуктивності, але і в отриманні додаткового прибутку. Мета дослідження - провести порівняльний аналіз госпрозрахунку Великобританії та Литви на прикладі бухгалтерії транспортної компанії Великобританії. Цілі дослідження: 1. Розкрити дискурс витрат та їх облік в контексті Сполученого Королівства і Литви, підкресливши загальні особливості та відмінності концепцій, що використовуються в обох країнах. 2. Визначити склад витрат в бухгалтерському обліку Великобританії, виділивши основні принципи. 3. Вивчити особливості документування
\end{abstract}


витрат, їх реєстрації та подання їх у фінансовій звітності Великобританії, визначаючи процес обліку витрат. Об’єкт дослідження: госпрозрахунок в Великобританії. Методи дослідження: аналіз наукової літератури та правових актів, статистичний аналіз даних, графічне представлення та інтерпретація.

Ключові слова: прямі витрати, накладні витрати, кошторисну документацію, фінансова звітність.

ИВАНАУСКЕНЕ, РУТА - бакалавр Мариямпольського университета прикладных наук (Мариямполь, Литва) E-mail: ruta.jaruseviciute@gmail.com

ORCID iD: http://orcid.org/0000-0002-6877-6003

ПЯТРОШЕНЕ, БІРУТЕ - лектор Мариямпольського университета прикладных наук (Маряямполь, Литва) E-mail: bir.petr@mkolegija.lt

ORCID iD: http://orcid.org/0000-0002-5160-8249

\title{
УЧЕТ РАСХОДОВ НА ПРЕДПРИЯТИИ ТРАНСПОРТНЫХ УСЛУГ: ПРИМЕР ВЕЛИКОБРИТАНИИ
}

\begin{abstract}
Аннотация
Учет затрат возник из истории производства. Европейская промышленная революция 18-19 веков и сопутствующая модернизация промышленности за счет ее механизации вызвали растущую потребность в точных производственных затратах. Необходимо было регистрировать производственные затраты по принципу двойной записи. Хотя учет затрат зародился в производственном секторе, его современные области применения охватывают широкий спектр экономической деятельности. Сегодня хозрасчет практикуется в различных секторах промышленности, производства, торговли и услуг. Организации государственного сектора, а именно правительства, различных ведомств, также используют учет затрат для определения своей эффективности и прогнозирования возможностей для улучшения. Учет затрат - это система, используемая для определения затрат, понесенных бизнесом или другой организацией. Это можно определить как систему, используемую для записи данных о затратах и определения стоимости производства продукта или предоставления услуги. Руководители используют информацию, собранную во время учета затрат, для контроля затрат и повышения прибыльности бизнеса. Проблема исследования. Понимание того, как меняются затраты при изменении производительности, является важной частью планирования, контроля и принятия решений. Существует несколько способов оценки и анализа затрат, согласно Шармана, поэтому многие компании не хотят менять свои старые методы и системы расчета затрат. Владельцы этих компаний неохотно принимают изменения в компании, полагаясь на высокие затраты на замену старой системы, которые могут возникнуть из-за внедрения новой системы, а также на нежелание бухгалтерского персонала изучать новые методы и принимаю нововведения. Между тем Окунбор утверждает, что затраты следует использовать для получения прибыли, поэтому возникает вопрос: может ли учет затрат и результаты, которые он дает, действительно помочь не только в достижении более эффективных результатов производительности, но и в получении дополнительной прибыли. Цель исследования - провести сравнительный анализ хозрасчета Великобритании и Литвы на примере бухгалтерии транспортной компании Великобритании. Цели исследования: 1. Раскрыть дискурс затрат и их учет в контексте Соединенного Королевства и Литвы, подчеркнув общие сходства и различия концепций, используемых в обеих странах. 2. Определить состав затрат в бухгалтерском учете в Великобритании, выделив основные принципы. 3. Изучить особенности документирования затрат, их регистрации и представления в финансовой отчетности Великобритании, определяя процесс учета затрат. Объект исследования: хозрасчет в Великобритании. Методы исследования: анализ научной литературы и правовых актов, статистический анализ данных, графическое представление и интерпретация.
\end{abstract}

Ключевые слова: прямые затраты, накладные расходы, сметная документация, финансовая отчетность.

(C) The Author(s) 2021

is is an open access article under

the Creative Commons CC BY license
Received date 07.02.2021

Accepted date 17.02.2021

Published date 07.03.2021

How to cite: Ivanauskiene, Ruta \& Petrošiene, Birute. Cost accouting at transport services enterprise: the case of the united Kingdom. Humanities studies: Collection of Scientific Papers. Zaporizhzhia: Zaporizhzhia National University, 2021. 7 (84), P. 102-112.

doi: https://doi.org/10.26661/hst-2020-7-84-12 